УДК 37.015.31:33

DOI:

Олександр Шпак, доктор педагогічних наук, професор Національного педагогічного університету імені М.П. Драгоманова, м. Київ Світлана Булавенко, кандидат педагогічних наук, докторант Інституту проблем виховання НАПН України

Наталія Примаченко, кандидат педагогічних наук, член Національної спілки журналістів України Дрогобицький державний педагогічний університет імені Івана Франка

\title{
ФОРМУВАННЯ ЖИТТЕВО ВАЖЛИВИХ ЕКОНОМІЧНИХ КОМПЕТЕНТНОСТЕЙ У НАВЧАЛЬНІЙ ДІЯЛЬНОСТІ
}

Економічна освіта, на нашу думку, може не тільки створювати спеціальні економічні знання та навички, актуальні в сучасних умовах, але і розвивати сочуіально-заявлені особистісні якості (ініціативність, незалежність, компетентність), формувати моральні та цінні мотиви господарської діяльності (мотиви соціальної відповідальності, творче співробітництво у прочесі соччіально значимої діяльності, досягнення міцчного соичіальнопрофесійного статусу, матеріального добробуту). Тому дуже важливим завданням сучасної освіти є формування економічної компетенції саме на уроках економіки. У статті охарактеризовано актуальність формування життєво важливих економічних компетентностей, розглядається зміст, складові та шляхи формування економічних знань і вмінь учнів, приділяється значна увага основним вимогам до рівня підготовки учнів з економіки.

Ключові слова: економічні компетенції; економічна освіта; методи та форми економічної освіти; иляхи формування економічних компетенциій.

Jim. 8.

Oleksandr Shpak, Doctor of Sciences (Pedagogy), Professor National Mukhaylo Drahomanov Pedagogical University Svitlana Bulavenko, Ph.D.(Pedagogy), Doctoral Student of the Institute of Education Problems of the National Academy of Sciences of Ukraine

Nataliya Prymachenko, Ph.D.(Pedagogy), Member of the National Union of Journalists of Ukraine Drohobych Ivan Franko State Pedagogical University

\section{THE FORMATION OF THE VITAL ECONOMIC COMPETENCIES IN THE PROCESS OFTRAINING ACTIVITIES}

Economic education, in our opinion, can not only create special economic knowledge and skills relevant in modern conditions, but also develop the socially-claimed personality qualities (initiative, independence, entrepreneurship), to form moral and value motives of economic activity (motives of social responsibility, creative cooperation in the process of socially meaningful activity, achievement of strong socio-professional status, material well-being). Therefore, a very important task of modern education is the formation of economic competence precisely at the lessons of the economy. Under the economic competence of a modern student they understand the totality of economic knowledge and practical skills, economic culture and thinking, experience, the presence of sustainable needs and interest in professional competence. Scientists define the following components of economic competence: a set of economic knowledge; economic consciousness; economic thinking; economic quality.

Formation of economic competence in students takes place in the process of acquiring various economic knowledge, development of skills and abilities, management and solving of problem situations that arise in the educational process and the life of students. The development of economic competence not only reflects the depth of knowledge of economics in students, but also helps to increase their skills, abilities, and improve their personal qualities. Formation and development of components of economic competence are provided by the corresponding complexes of theoretical knowledge and practical actions, their activation with the active participation of teachers of economy.

The main ways of forming an economically competent personality of a student are: adherence to the necessary minimum amount of knowledge, skills and abilities of the students specified in the "Concept of Development of Economic Education"; to provide the educational process with an appropriate material and technical base; providing students with the information resources of the Internet on economics education and economics; use of interactive forms and methods of training; widespread use of interdisciplinary connections; availability of an appropriate training and methodological base on economics; the combination of theoretical teaching material with life and the formation of the practical application of the knowledge gained; involvement of students into extracurricular work in economics; participation in competitions and contests on economics.

(c) О. Шпак, С. Булавенко,

Н. Примаченко, 2018 


\section{ФОРМУВАННЯЖИТТЕВО ВАЖЛИВИХ ЕКОНОМІЧНИХ КОМПЕТЕНТНОСТЕЙ У НАВЧАЛЬНІЙ ДІЯЛЬНОСТІ}

Consequently, the formation of the economic competence of pupils in KSSO at the lessons of the economy will be effective when it is systematic and consistent. Indeed, economic competence is the economic knowledge and experience acquired due to education and training, oriented towards the formation of the student as a subject of life and culture, ones active integration into society.

Keywords: economic competences; economic education; the methods and forms of economic education; the ways of formation of economic competences.

П остановка проблеми. Соціальноекономічні перетворення в країні призвели до зміни рівня життя людей, що спричинило необхідність адаптації особистості до сучасних ринкових умов, підготовки грамотних фахівців в різних галузях, які займають активну позицію у вирішенні своїх професійних завдань. Це спричинило за собою виникнення проблеми пошуку ефективного вирішення завдань підвищення якості економічної освіти учнів як одного з провідних напрямків вдосконалення української освіти, відображеної в усіх нормативно-правових документах.

3 переходом України до економіки ринкового типу та євроінтеграцією, загальноосвітня школа стала перед необхідністю радикального оновлення змісту освіти, в тому числі виникла необхідність економічної освіти, якій до цього приділялася дуже незначна увага.

Старшокласник, який готується до самостійного життя незалежно від обраної галузі професійної діяльності повинен мати (i це становить значну частину соціального замовлення вимог до випускника) сформовані життєво важливі економічні компетентності, а значить, міцні економічні знання, повинен вміти орієнтуватися в економічних питаннях і проблемах, що дозволить впевнено почувати себе в житті. Випускнику просто життєво необхідно морально, психологічно і практично бути готовим до праці в умовах ринкової економіки; йому необхідно допомогти усвідомити, що особистий успіх залежить від їх професійної та економічної грамотності, працьовитості, ініціативи, підприємливості та творчості [4].

У зв'язку з цим освітня система покликана вирішити важливу задачу забезпечення трудової підготовки старшокласників в нерозривному зв'язку з економічною освітою і вихованням, які передбачають формування тих знань, умінь i навичок, потреб та інтересів, характеру мислення, поведінки і діяльності, які відповідають принципам і нормам господарювання в нових соціальноекономічних умовах.

Метою статті є ознайомлення 3 життєво важливими економічними компетенціями, та визначити шляхи їх формування.

Аналіз актуальних досліджень. Питанням економічної освіти і виховання школярів присвячені роботи багатьох дослідників. До теперішнього часу різними авторами підготовлені програми, навчальні посібники, методичні рекомендації для початкової школи; з економічного виховання та освітидітей молодшогошкільноговіку(М.Л. Алфьорова, Г.Х.Гебеков, Е.Н. Землянська, І.А. Сасова, Л.С. Чернер та ін.). Аналіз робіт вищевказаних дослідників дозволяє зробити висновок про те, що економічна підготовка школярів повинна здійснюватися 3 перших днів навчання в школі, а вивчення економіки в початковій школі можливо як в навчальному процесі, у позаурочній діяльності, так і в умовах додаткової освіти.

Проблемуформування економічноїкомпетентності учнів відображено у працях багатьох фахівців. Л.О. Ануфрієва під “економічною компетентністю" розуміє "сукупність економічних знань і практичних умінь, досвіду, економічної культури та мислення, наявність стійкої потреби та інтересу до професійної компетентності" [3]. Структуру економічної компетентності досліджували M.I. Бабкін, С.С. Бахтєєва та I.А. Сасова, сутність економічної компетентності вони розкривають через характеристику набору економічних якостей особистості. Л.С. Бляхман вважає, що для особистості важливим $\epsilon$ формування економічного мислення [8]. У працях О.І. Джалілової,Т.Х. Ємтиль, Б.І. Іткіна, Л.М. Фалевич зміст економічної компетентності розглядається через характеристику обсягу знань, умінь та навичок в економічній сфері. Так, Л.М. Фалевич визначає економічну компетентність як ступінь оволодіння економічними знаннями, вміннями та навичками, набором можливостей розв' язування і прогнозування економічних проблем на основі економічного мислення [2].

Виклад основного матеріалу. Історично склалося ставлення до економічної освіти як до частини професійної та трудової підготовки, а не як до самостійно-спрямованої лінії виховання і освіти в рамках освітнього простору установи. У зв'язку з цим намітився ряд протиріч, а саме:

- між об'єктивно існуючою необхідністю керівництва соціальним становленням старшокласників і недостатнім усвідомленням педагогічною громадськістю можливостей економічної підготовки в цьому процесі;

- традиційним змістом, формами, методами здійснюваної економічної підготовки та необхідністю використання інноваційних технологій у формуванні соціально значущих 


\section{ФОРМУВАННЯЖИТТЕВО ВАЖЛИВИХ ЕКОНОМІЧНИХ КОМПЕТЕНТНОСТЕЙ}

У НАВЧАЛЬНІЙ ДІЯЛЬНОСТІ

якостей особистості, знань, умінь, досвіду соціально-економічної діяльності школярів, що сприяє соціальному самовизначенню і становленню особистості;

- між інноваційними процесами, що проходять в суспільній свідомості молоді в зв'язку 3 об'єктивною потребою в економічній освіті, і наявністю стереотипного підходу до передачі цієї галузі знань;

- між нагальною потребою в безперервності, наступності та універсальності освіти на всіх етапах освіти (довузівської, вузівської, поствузівскої), а також нерозробленістю або неузгодженістю між наявними для цього навчальними планами, програмами, змістом, формами і методами отримання освіти, що значно знижує можливість отримання економічної освіти, адекватно відповідає потребам часу і суспільства [2].

Вирішення цього завдання ускладнене тим, що у більшості населення, в тому числі у молоді, не сформовані ціннісні орієнтації на вільну економічну діяльність, розвиток творчої і підприємницької ініціативи, багатьом не вистачає соціальнозначущих знань і умінь, досвіду самостійної економічної діяльності. Соціальне становлення молоді відбувається в умовах, коли природне прагнення до самоствердження, успіху стикається зі все зростаючою конкуренцією, високими вимогами до особистості на ринку праці.

Економічна освіта, на наш погляд, може не тільки формувати спеціальні економічні знання і вміння, актуальні в сучасних умовах, а й розвивати соціально-затребувані якості особистості (ініціативність, самостійність, підприємливість), формувати морально-ціннісні мотиви економічної діяльності (мотиви соціальної відповідальності, творчої співпраці в процесі соціально-значимої діяльності, досягнення міцного соціально-професійного статусу, матеріального благополуччя).

У новому Державному стандарті базової i повної загальної середньої освіти сказано, що одним з головних результатів освоєння загальної освіти є освоєння способів діяльності, які можна застосувати як в рамках освітнього процесу, так і при вирішенні проблем в реальних життєвих ситуаціях [1].

Основні вимоги до рівня підготовки випускників школи $з$ економіки, які сьогодні висуваються, полягають у тому, що учень повинен знати і розуміти:

- види економічних систем, форми організації виробництва; основні джерела доходів і статті витрат сімейного бюджету, можливі види заощаджень, основні податки, що сплачуються громадянами, форми державної підтримки безробітних та малозабезпечених [5].

Також учень повинен вміти (володіти способами пізнавальної діяльності):

- наводити приклади: елементів традиційної, централізованої (командної) і ринкової систем в змішаній економіці, поділу праці, дії ринкового механізму, різних видів ринків;

- описувати: економічну сферу життя суспільства, економічні системи, раціональне поведінка споживача і роль реклами, раціональне поведінку людини, яка розміщує свої заощадження, дію ринкового механізму, роль конкуренції, діяльність підприємця, роль держави в ринковій економіці, форми заробітної плати та стимулювання праці;

- пояснювати; походження грошей, взаємовигідність добровільного обміну, вигоди і труднощі підприємницької діяльності, а також роботи по найму [2].

Учень повинен застосовувати отримані знання і вміння в практичній діяльності та повсякденному житті обчислювати на умовних прикладах: дохід від банківських вкладів, дохід від цінних паперів, валового і чистого прибутку, індивідуальний прибутковий податок, величину страхового внеску. Тобто мати сформовані предметні компетенції 3 економіки.

В новому Державному стандарті базової i повної загальної середньої освіти так дано визначення предметної (галузева) компетентності - “це набутий учнями у процесі навчання досвід специфічної для певного предмета діяльності, пов'язаної із засвоєнням, розумінням i застосуванням нових знань; предметна компетенція - сукупність знань, умінь та характерних рис у межах змісту конкретного предмета, необхідних для виконання учнями певних дій з метою розв'язання навчальних проблем, задач, ситуацій” [1].

Тому дуже важливим завданням сучасної освіти є формування економічної компетентності саме на уроках економіки. Під економічною компетентністю сучасного учня розуміють сукупність економічних знань та практичних вмінь, економічної культури та мислення, досвіду, наявність стійкої потреби та інтересу до професійної компетентності. Вчені визначають такі складові економічної компетентності:

- сукупність економічних знань;

- економічна свідомість;

- економічне мислення;

- економічні якості. 


\section{ФОРМУВАННЯЖИТТЕВО ВАЖЛИВИХ ЕКОНОМІЧНИХ КОМПЕТЕНТНОСТЕЙ У НАВЧАЛЬНІЙ ДІЯЛЬНОСТІ}

Формування економічної компетентності в учнів відбувається у процесі набугтя різноманітних економічних знань, розвитку умінь та навичок, управління і розв'язання проблемних ситуацій, що виникають у навчальному процесі та житті учнів. Розвиток економічної компетентності не тільки відображає глибину знань з економіки в учнів, але й допомагає підвищити рівень їхніх навичок, умінь, удосконалити свої особистісні якості.

У контексті вирішення проблеми економічної освіти школярів йдеться про економічну підготовку всіх учнів, де перед учителем постає завдання передачі їм базових знань про особисту, сімейну економіку, підготовку до виробничоекономічної діяльності в умовах різних видів власності, різноманіття форм організації праці, ознайомлення з різними професіями та основами соціально-економічного захисту молоді в умовах формування ринкових відносин, тобто формування основи для підготовки покоління, здатного до життєвого і професійного самовизначення в умовах ринкових відносин. Однак сама по собі наявність базових економічних знань не $\epsilon$ запорукою формування економічно грамотної особистості. Тільки активна позиція школярів в процесі економічної освіти дає можливість вибору кожного учня індивідуальної траєкторії свого розвитку, простору для самореалізації, що забезпечується міцними економічними знаннями, вміннями і навичками і зумовлює повноцінну життєдіяльність в сучасних ринкових умовах [7].

Економічна освіта в ранньому віці допомагає дітям розвинути економічне мислення, освоїти понятійний апарат, такий необхідний для орієнтації в сучасному ринковому світі.

Метою економічної освіти є придбання елементарних навичок поведінки в умовах ринку, створення понятійної основи для подальшого, більш глибокого вивчення економіки в старших класах. Основними завданнями є:

- в сфері навчання - освоєння основ знань про сучасну економіку, принципи і закономірності їі функціонування, умінь економічної діяльності;

- в сфері самосвідомості - осмислення свого індивідуального потенціалу, формування усвідомленої громадянської економічної поведінки;

- в сфері мотивації - розвиток інтересу до проблем економіки країни і сім'ї, постійної потреби в нових знаннях, прагнення до самовираження і самореалізації, що має стати засобом соціального захисту, адаптацією до умов ринку [3].

Реалізація поставлених завдань і мети може йти шляхом інтеграції економіки з навчальними предметами, де економічні знання будуть знаходити практичний вихід (математичні розрахунки, якості особистості - працьовитість, підприємливість, ощадливість тощо).

Вчителю при викладанні економіки необхідно в своїй діяльності керуватися принципами розвиваючого навчання:

- спрямованість навчання на розвиток особистості учня;

- суб'єктна позиція учня в пізнавальній діяльності;

- стимулювання учня до самостійної діяльності;

- розвиток адекватної самооцінки;

- забезпечення вмотивованості, усвідомленості;

- діяльний підхід;

- орієнтація на співпрацю;

- поетапність формування знань, умінь;

- використання життєвого досвіду учнів;

- орієнтація на посильність, науковість знань;

- комфортність учасників освітнього процесу [5].

Не зважаючи на різні підходи до викладання, вивчення економіки в школі спрямоване на досягнення таких цілей:

- освоєння системи знань, що спираються на основи економічної науки, про структуру і логіку функціонування економіки, про економічну поведінку людей, системі цінностей вільного і відповідального вибору, необхідних для взаємодії 3 соціальним середовищем і для підготовки до вивчення соціально-економічних і гуманітарних дисциплін в майбутньому;

- ознайомлення зі способами пізнавальної, комунікативної і практичної діяльності в умовах ринкової економіки, необхідними для участі в економічному житті суспільства і держави;

- оволодіння умінням застосовувати отримані знання для вирішення типових пізнавальних i практичних економічних задач і освоювати соціальні ролі споживача, працівника, власника;

- розвиток соціального кругозору особистості в підлітковому віці, інтересу до вивчення дисциплін соціально-економічного циклу; здатності до особистого самовизначення і самореалізаціі;

- виховання прихильності до гуманістичних і демократичних цінностей, економічного способу мислення, соціальної відповідальності [6].

Придбання компетентності:

- в сфері цивільно-громадської діяльності, міжособистісних відносин - освоєння на інформаційномута практичномурівнях основних соціальних ролей, найбільш важливих в економічній діяльності (споживача, працівника, власника); 
- в сфері пізнавальної діяльності- розпізнавання на основі отриманих знань різних економічних явищ і їх взаємозв'язку;

- в сфері трудової діяльності - розкриття порівняльних вигод і труднощів підприємницької діяльності і роботи за наймом, розуміння закономірностей ринку праці, причин та форм безробіття;

- в сфері масової комунікації - розвиток в учнів здатності розглядати події з економічної точки зору, використовуючи окремі прийоми економічного аналізу, критично осмислювати економічну інформацію, що міститься в засобах масової інформації, і висловлювати власну аргументовану думку [2].

Реалізація зазначених цілей і формування названих компетентностей досягається в результаті освоєння такого змісту освіти:

- ціннісні орієнтири: свобода вибору, відповідальність за наслідки вибору, повага прав власності незалежно від іiі форм, праця, законослухняність в сфері економічної діяльності;

- знання: економічна сфера життя суспільства, товари та послуги, обмеженість ресурсів, вибір і альтернативна вартість, виробництво, продуктивність праці, поділ праці та спеціалізація, економічні системи, власність, обмін, форми торгівлі, споживач і реклама, ринок і ринковий механізм, попит і пропозиція, еластичність попиту, гроші, інфляція, банки і їх операції, банківські послуги, що надаються громадянам, сімейний бюджет, реальні і номінальні доходи сім'ї, нерівність доходів, економічні заходи соціальної підтримки, форми заощаджень населення: банківські вклади, цінні папери, готівкова валюта, вибір між надійністю і прибутковістю заощаджень, страхові послуги, що надаються громадянам, підприємництво, витрати, виручка, прибуток, основні форми організації виробництва, акції та інші цінні папери, фондовий ринок (біржа), ринок праці, заробітна плата і стимулювання праці, безробіття, види безробіття, державна політика соціальної підтримки безробітних, роль профспілок, економічні функції і цілі держави, основні види державних витрат, доходи держави, податки, що сплачуються громадянами;

- способи діяльності: співвіднесення доходів і витрат сімейного бюджету, вибір найкращого способу розміщення заощаджень, виконання найпростіших розрахункових завдань 3 економічним змістом;

- досвід: досвід економічної діяльності в межах дієздатності підлітка, досвід раціональної поведінки в якості споживача, члена сім'ї, власника ресурсів, досвід оцінки своєї поведінки
3 точки зору його економічної ефективності [8].

Формування економічної компетентності в учнів 33СО сприяє розвитку інтелектуальної, мотиваційної, предметно-практичної сфер розвитку особистості, а також розвитку особистості в цілому.

Формування та розвиток складових економічної компетентності забезпечуються відповідними комплексами теоретичних знань та практичних дій, їх активізації за активної участі учителів економіки [4].

Основними шляхами формування економічно компетентної особистості учня є:

- дотримання необхідного мінімального обсягу знань, умінь і навичок учнів, зазначених у "Концепції розвиткуекономічної освіти";

- забезпечення освітнього процесу належною матеріально-технічною базою;

- забезпечення учнів інформаційними ресурсами Internet 3 економічної освіти та економіки;

- використання інтерактивних форм та методів навчання;

- широке використання міжпредметних зв'язків;

- наявність належної навчально-методичної бази з економіки;

-поєднання теоретичного навчального матеріалу 3 життям та формування вміння практичного застосування отриманих знань;

- залучення учнів до позакласної роботи 3 економіки;

- участь в олімпіадах та конкурсах з економіки.

Висновок. Отже, формування економічної компетентності учнів 33СО на уроках економіки буде ефективним в тому випадку, коли буде системним та послідовним. Адже, економічна компетентність - це економічні знання і досвід, набугі завдяки навчанню і вихованню, зорієнтовані на становлення учня як суб'єкта життя й культури, його активну інтеграцію в суспільство.

\section{ЛІТЕРАТУРА}

1. Постанова кабінету міністрів України Про затвердження Державного стандарту базової і повної загальної середньої освіти [Електронний pecypc]. - Режим доступу: http://www.mon.gov.ua/ ua/often-requested/state-standard?_2.exe

2. Бицюра Ю. Формування основ економічної компетентності учнів / Ю. Бицюра // Завуч. 2006.- № 20-21. - С. 4-5.

3. Економічна компетентність в системі післядипломної педагогічної освіти. Навчальний посібник / За ред. Г. А. Дмитренка. - К.: ЦІППО, 2008. $-125 \mathrm{c}$. 
4. Ковтун Г. І., Мартиненко О. В. До питання формування економічної компетентності учнів [Електронний ресурс]. - Режим доступу: http:// irbis-nbuv.gov.ua/cgi-bin/irbis_nbuv/cgiirbis_64.exe

5. Лелека С.В. Активізація пізнавальної діяльності учнів на уроках економіки / С.В. Лелека // Економіка в школах України. - 2006. - №4(17) - C. $8-11$.

6. Овсюк Н. Формування економічної компетентності у процесі вивчення географії та основ економіки / Н. Овсюк // Географія та основи економіки в школі. - 2011.- № 1. - С. 37-41.

7. Овчарук О. Компетентність як ключ до оновлення змісту освіти / О. Овчарук // Стратегія реформування освіти в Україні. - К.: “К.І.С.”, 2003. - C. 13-41.

8. Топузов О. Компетентнісний підхід до навчання / О. Топузов, Л. Вішкініні //Географія та основи економіки в школі. - 2011. - № 5. - С. 34 37.

\section{REFERENCES}

1. Postanova kabinetu ministriv Ukrainu Pro zatverdzhennya Detzhavnogo standartu bazovoi I povnoi zagalnoi serednoi osvitu [The Resolution of the Cabinet of Ministers of Ukraine on Approval of the State Standard for Basic and Complete Secondary Education]. [Electronic resource]. Available at: http:/ /www.mon.gov.ua/ua/often-requested/statestandards/ [in Ukrainian].

2. Butsyura, Y. (2006). Formuvannya osnov ekonomichnoi kompetentnosti uchniv [The formation of the bases of economic competence of students]. Zavuch. No. 20-21, pp. 4-5. [in Ukrainian].
3. Ekonomichna kompetentnist v sustemi pislyaduplomnoi pedagogichnoi osvitu (2008). [Economic competence in the system of postgraduate pedagogical education]. Tutorial. (Ed.). G.A. Dmutrenko. Kyiv: CIPPO, 125 p. [in Ukrainian].

4. Kovtun, G.I. \& Martynenko, O.V. Do pytannya formuvannya ekonomichnoi kompetentnosti uchniv [The question of forming the economic competence of students]. [Electronic resource]. Available at: http:/ /irbis-nbuv.gov.ua/cgi-bin/irbis_nbuv/cgiirbis_64.exe? [in Ukrainian].

5. Leleka, S.V. (2006). Aktuvizatsiya piznavalnoi diyalnosti uchniv na urokach ekonomiky [An activation of cognitive activity of students at economics lessons]. Economics in schools of Ukraine. Vol.4 (17), pp. 8 - 11. [in Ukrainian].

6. Ovsyuk, N. (2011). Formuvannya ekonomichnoi kompetentnosti u protsesi vuvchennya geografii ta osnov ekonomiky [The Formation of economic competence in the process of studying Geography and fundamentals of Economics]. Geography and Basics of Economics in School. No. 1, pp.37-41. [in Ukrainian].

7. Ovcharuk, O. (2003). Kompetentnist yak klyuch do onovlennya zmistu [Competence as a key to updating the content of education]. A strategy of reforming the education in Ukraine. Kyiv: "K.I.S.", pp. 13-41. [in Ukrainian].

8. Topyzov, O. \& Vishкinini, L. (2011). Комpetentnisny pidchid do navchannea [Компетентнісний підхід до навчання]. Geography and Basics of Economics in School. No.5, pp. 3437. [in Ukrainian].

Стаття надійшла до редакції 26.07.2018

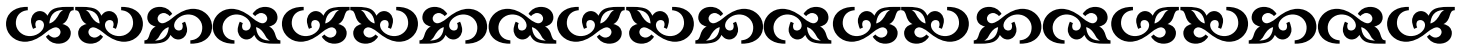

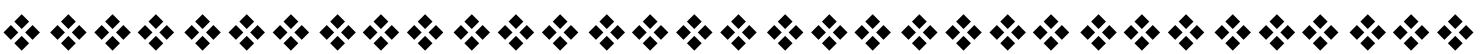

"Траия-ие одне з найчистіших і найшляхетнішихджерел емоиійного стану, радості діяння, творення. Фумқа, що народжена, збуджена, витончена в прачі, стає радісною, оптимістичною".

Василь Сухомлинський

украӥнський педагог

"Недостатньо тільки отримати знання; їх треба застосувати. Недостатньо тільки бажати; треба діяти”.

$\check{\mathscr{Y} о г а н н ~ В о л ь б б г а н г ~ б о н ~ Т е т е ~}$ німеиький поет, прозаїк, драматург

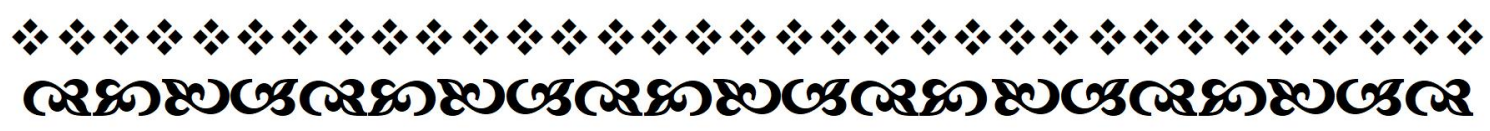

